\title{
Expression of somatostatin receptor subtypes in human thyroid tumors: the immunohistochemical and molecular biology (RT-PCR) investigation
}

\author{
Hanna Pisarek*1, Tomasz Stępień ${ }^{2}$, Robert Kubiak ${ }^{3}$, Edyta Borkowska ${ }^{4}$ and \\ Marek Pawlikowski ${ }^{1}$
}

Address: ${ }^{1}$ Department of Neuroendocrinology, Medical University, Łódź, Poland, ${ }^{2}$ Department of General and Endocrine Surgery, Medical University, Łódź, Poland, ${ }^{3}$ Department of Pathology of Tumors, Medical University, tódź, Poland and ${ }^{4}$ Department of Medical Genetics, Medical University, Łódź, Poland

Email: Hanna Pisarek* - h.pisarek@kardio-sterling.lodz.pl; Tomasz Stępień - tomsamaz@wp.pl; Robert Kubiak - rpkubiak@interia.pl; Edyta Borkowska - edyta.borkowska@kardio-sterling.lodz.pl; Marek Pawlikowski - pawlikowski.m@wp.pl

* Corresponding author

\section{Published: 27 January 2009}

Thyroid Research 2009, 2:1 doi:10.1/86/1756-66/4-2-I
Received: 21 November 2008

Accepted: 27 January 2009

This article is available from: http://www.thyroidresearchjournal.com/content/2/I/I

(c) 2009 Pisarek et al; licensee BioMed Central Ltd.

This is an Open Access article distributed under the terms of the Creative Commons Attribution License (http://creativecommons.org/licenses/by/2.0), which permits unrestricted use, distribution, and reproduction in any medium, provided the original work is properly cited.

\begin{abstract}
Human endocrine tumors often express the somatostatin receptors SSTR I-5 with different intensity. It has been widely investigated their distribution in pituitary adenomas, brain tumors, adrenal tumors and neuroendocrine tumors in gastrointestinal tract (NET). Some of studies also concern the expression of SSTRs in thyroid tumors but they are mainly limited to parafollicular C cells - derived medullary thyroid carcinomas (MTC). Results of SSTR I-5 detection in other thyroid pathologies like follicular adenomas and papillary cancers are still scarce and often controversial, depending of investigation method used. The aim of this study was to report the presence of all the 5 subtypes of SSTR (including 2A and 2B SSTR isoforms) in some surgically treated human thyroid tumors by means of immunohistochemistry and real-time PCR method and to correlate the results obtained with both techniques. SSTR I protein was expressed in $88.8 \%$ of investigated cases, SSTR $2 \mathrm{~A}$ and $2 \mathrm{~B}$ both in $44.4 \%$, SSTR 3 in 55.5\%, SSTR 4 in $11.2 \%$ and SSTR 5 in $33.3 \%$. SSTR $I$ is the dominant form in the thyroid gland tumor and hyperplasia. We found positive confirmation of both methods in $88.8 \%$ for SSTR I, 2A, 3 subtypes, in $22.2 \%$ for SSTR 4 and in $100 \%$ for SSTR 5 . It suggests that somatostatin multiligand analogs or selective SSTR I agonists may be used in thyroid tumors treatment.
\end{abstract}

\section{Background}

Somatostatin (SST) as well as its synthetic analogs are engaged in regulation of hormones secretion in different ways and this action depends on specific receptors expression which are present on the target cells. Five subtypes of the SST receptor have been identified so far, i.e. SSTR 1-5. SSTR 2 is present in two splicing variants (2A and $2 \mathrm{~B}$ ) $[1,2]$. All of them belong to a group of 7 transmembrane domains linked with the G protein [3] and are encoded by 5 genes which are present on separate chromosomes $[4,5]$. In the cell the SST receptors can be found on the cell membrane or in the cytoplasm. Particular SSTR subtypes can occur alone or be grouped together in the same cell. SSTR are present both in normal and in tumor tissues which enables their response to applied SST analogs [6]. Human endocrine tumors often express the somatostatin recep- 
tors SSTR 1-5 with different intensity. It has been widely investigated their distribution in pituitary adenomas, brain tumors, adrenal tumors and neuroendocrine tumors in gastrointestinal tract (NET). Some of studies also concern the expression of SSTRs in thyroid tumors but they are mainly limited to parafollicular C cells derived medullary thyroid carcinomas (MTC) [7-9]. Results of SSTR 1-5 detection in other thyroid pathologies like follicular adenomas and papillary cancers are still scarce and often controversial [10-13] depending of investigation method used (see Table 1).

Majority of studies applied the molecular biology methods of SSTRs investigation. These include the reverse transcriptase PCR (RT-PCR), in situ hybridization (ISH), real-time PCR (RT-PCR) and Northern-blotting which are searching the expression of receptors at the level of mRNA. Apart from that, molecular biology methods are often burdened with some limitations like the necessity to use frozen tissue from surgical samples, very expensive reagents to perform the molecular reaction and sometimes gives false positive results. SSTRs investigation by immunohistochemical methods (IHC) is searching the expression of receptors at the level of receptor protein and gives us insight into receptor's cellular localization. The immunohistochemical technique can be also performed on paraffin embedded tissue specimens obtained from surgically removed tumors which are routinely used for histopathological examinations and seems to be the best ex vivo in vitro method in detecting cellular distribution of SST receptors [14]. In our previous study we proved high efficacy of immunohistochemical detection of SSTR expression in human pituitary adenomas, adrenal gland tumors and neuroendocrine tumors using antibodies specific for a given receptor subtype [15-17]. This method should be considered supplementary or even equally effective as methods of molecular biology or in vivo receptor radiodiagnostic imaging.

The aim of this study was to report the presence of all the 5 subtypes of SSTR (including 2A and 2B SSTR isoforms) in some surgically treated human thyroid tumors by means of immunohistochemistry and real-time PCR method and to correlate the results obtained with both techniques.

\section{Methods}

In this study 9 samples obtained during surgically treated thyroid diseases were assessed. The material was obtained from 7 women and 2 men aged between 32 and 79 years (mean age 56 years). Four samples (nr 1-4) were diagnosed histopathologically as thyroid cancers, five samples (nr 6-10) concerned benign lesions of the thyroid gland (Table 2). This project received the approval of the Ethics Committee of Medical University of Łódź nr: RNN/97/ 06/KE dated 16.05.2006.

\section{Immunohistochemistry}

Bouin's fixed, dehydrated and paraffin embedded $8-\mu \mathrm{m}$ sections were immunostained using commercially available rabbit polyclonal antisera raised against carboxyl-terminal fragments of specific human somatostatin receptor subtypes (GRAMSCH Laboratories, Schwabhausen, Germany): SSTR 1 (named SS-840 antibody, corresponding to amino acid sequence 377-391 of the receptor's peptide chain), SSTR 2A (SS-800, specific for 355-369 sequence),

Table I: Expression of somatostatin receptors subtypes in some thyroid lesions - the previous studies

\begin{tabular}{|c|c|c|c|c|}
\hline Lesion type & SSTR detected & Material & Methods & Authors \\
\hline \multirow[t]{2}{*}{ Follicular carcinoma } & $\begin{array}{l}\text { SSTR I, 2A, 2B, } 4,5-100 \% \text {, SSTR } \\
\text { 3-negative. }\end{array}$ & $\begin{array}{l}\text { Formalin fixed paraffin embedded } \\
\text { sections. }\end{array}$ & $\mathrm{IHC}$ & {$[12]$} \\
\hline & $\begin{array}{l}\text { SSTR I, } 3 \text {-moderate, SSTR 2- } \\
\text { faint, SSTR 5-strong, SSTR 4- } \\
\text { negative. }\end{array}$ & $\begin{array}{l}\text { Thyroid cancer cell line } \\
\text { monolayer and xenograft (MRO- } \\
87, \text { WRO-82). }\end{array}$ & $\begin{array}{l}\text { Semiquantitative RT-PCR with } \\
\text { ethidium bromide. }\end{array}$ & {$[10]$} \\
\hline \multirow[t]{5}{*}{ Papillary carcinoma } & $\begin{array}{l}\text { SSTR I, 2B, 3, } 4-83 \% \text {; SSTR 2A- } \\
66 \% \text {, SSTR 5-100\%. }\end{array}$ & $\begin{array}{l}\text { Formalin fixed paraffin embedded } \\
\text { sections. }\end{array}$ & $\mathrm{IHC}$ & {$[12]$} \\
\hline & $\begin{array}{l}\text { SSTR I, 3, } 5 \text {-moderate, SSTR } 2 \text { - } \\
\text { faintly detectable, SSTR } 4 \text { - } \\
\text { negative. }\end{array}$ & $\begin{array}{l}\text { Thyroid cancer cell line } \\
\text { monolayer and xenograft (NPA } \\
87, \text { KAT-10). }\end{array}$ & $\begin{array}{l}\text { Semiquantitative RT-PCR with } \\
\text { ethidium bromide. }\end{array}$ & {$[10]$} \\
\hline & SSTR 2 -87\%. & Paraffin embedded sections. & $\mathrm{IHC}$ & {$[13]$} \\
\hline & $\begin{array}{l}\text { SSTR 2-68\%, SSTR 5-50\%, SSTR3 } \\
-31 \% \text {, SSTR I, } 4-\text { not found. }\end{array}$ & Frozen tissue. & RT-PCR & {$[13]$} \\
\hline & $\begin{array}{l}\text { SSTR I, 3, 4, 5-more than twice } \\
\text { the background, SSTR } 2 \text {-no } \\
\text { signal. }\end{array}$ & Frozen biopsied tumor tissue. & Northern blot analysis. & {$[21]$} \\
\hline Multinodular goiter (MNG) & $\begin{array}{l}\text { SSTR 2A, 3, } 4-82 \% \text {, SSTR 2B, 5- } \\
94 \% \text {, SSTR I-88\%. }\end{array}$ & $\begin{array}{l}\text { Formalin fixed paraffin embedded } \\
\text { sections. }\end{array}$ & $\mathrm{IHC}$ & {$[12]$} \\
\hline
\end{tabular}


Table 2: Expression of somatostatin receptor subtypes in some thyroid gland diseases determined by IHC

\begin{tabular}{|c|c|c|c|c|c|c|c|c|}
\hline No & No of patient & $\begin{array}{l}\text { Histopathological } \\
\text { determination }\end{array}$ & SSTR - I & SSTR - 2A & SSTR - 2B & SSTR - 3 & SSTR - 4 & SSTR - 5 \\
\hline P-I. & $\begin{array}{l}338542 \\
\text { F-56 years old }\end{array}$ & $\begin{array}{l}\text { Papillary } \\
\text { carcinoma }\end{array}$ & $\begin{array}{l}+++ \text { mem, part. } \\
\text { cytopl }\end{array}$ & $\begin{array}{l}+++ \text { mem, part. } \\
\text { cytopl }\end{array}$ & $\begin{array}{l}+ \text { mem, pale } \\
\text { cytopl }\end{array}$ & $\begin{array}{l}+/++ \\
\text { cytopl }\end{array}$ & $\begin{array}{l}\text { negative } \\
+ \text { single cells }\end{array}$ & ++ cytopl \\
\hline P-2. & $\begin{array}{l}333508 \\
\text { F-37 years old }\end{array}$ & $\begin{array}{l}\text { Papillary } \\
\text { carcinoma }\end{array}$ & $\begin{array}{l}+++ \\
\text { cytopl }\end{array}$ & $\begin{array}{l}++ \\
\text { mem/cytopl }\end{array}$ & $\begin{array}{l}++/+++ \\
\text { cytopl }\end{array}$ & $\begin{array}{l}++/+++ \\
\text { cytopl }\end{array}$ & $\begin{array}{l}\text {-/+++ } \\
\text { cytopl !!! }\end{array}$ & $\begin{array}{l}-/+++ \\
\text { cytopl }\end{array}$ \\
\hline P-3. & $\begin{array}{l}334708 \\
\text { F-79 years old }\end{array}$ & $\begin{array}{l}\text { Poorly } \\
\text { differentiated } \\
\text { carcinoma }\end{array}$ & $\begin{array}{l}++ \\
\text { mem/cytopl }\end{array}$ & $\begin{array}{l}+ \\
\text { mem/cytopl }\end{array}$ & $\begin{array}{l}+ \\
\text { mem/cytopl }\end{array}$ & $\begin{array}{l}++ \\
\text { cytopl }\end{array}$ & negative & $\begin{array}{l}+/-/+ \\
\text { cytopl }\end{array}$ \\
\hline P-4. & $\begin{array}{l}335385 \\
\text { M-69 years old }\end{array}$ & $\begin{array}{l}\text { Poorly } \\
\text { differentiated } \\
\text { carcinoma }\end{array}$ & $\begin{array}{l}+++ \\
\text { mem/cytopl }\end{array}$ & $+/-;$ & $\begin{array}{l}+ \\
\text { cytopl }\end{array}$ & $+/-$ & negative & $\begin{array}{l}+/-/++ \\
\text { cytopl }\end{array}$ \\
\hline P-6. & $\begin{array}{l}3323 I 4 \\
F-45 \text { years old }\end{array}$ & Lymphatic goiter & negative & negative & negative & negative & negative & $\begin{array}{l}+++ \\
\text { cytopl (in the } \\
\text { single follic. } \\
\text { struct.) }\end{array}$ \\
\hline P-7. & $\begin{array}{l}332142 \\
F-32 \text { years old }\end{array}$ & $\begin{array}{l}\text { Nodular } \\
\text { hyperplasia of } \\
\text { thyroid gland }\end{array}$ & $\begin{array}{l}++ \\
\text { cytopl }\end{array}$ & $\begin{array}{l}+ \\
\text { cytopl }\end{array}$ & $\begin{array}{l}++/+++ \\
\text { cytopl }\end{array}$ & $\begin{array}{l}+++ \\
\text { cytopl }\end{array}$ & negative & $\begin{array}{l}+++ \\
\text { cytopl }\end{array}$ \\
\hline P-8. & $\begin{array}{l}332567 \\
\text { M-73 years old }\end{array}$ & $\begin{array}{l}\text { Colloido-nodular } \\
\text { goiter. Follicular } \\
\text { adenoma }\end{array}$ & $\begin{array}{l}++/+++ \\
\text { cytopl }\end{array}$ & $\begin{array}{l}++ \\
\text { cytopl }\end{array}$ & $\begin{array}{l}+ \\
\text { cytopl }\end{array}$ & $\begin{array}{l}++/+++ \\
\text { cytopl }\end{array}$ & negative & $\begin{array}{l}+/++ \\
\text { cytopl }\end{array}$ \\
\hline P-9. & $\begin{array}{l}332131 \\
F-67 \text { years old }\end{array}$ & $\begin{array}{l}\text { Thyroid goiter } \\
\text { with signs of focal } \\
\text { hyperactivity }\end{array}$ & $\begin{array}{l}++ \\
\text { cytopl }\end{array}$ & $\begin{array}{l}+/- \\
\text { cytopl }\end{array}$ & $\begin{array}{l}++ \\
\text { cytopl }\end{array}$ & $\begin{array}{l}+ \\
\text { cytopl }\end{array}$ & negative & $\begin{array}{l}+ \\
\text { cytopl }\end{array}$ \\
\hline P-10. & $\begin{array}{l}332205 \\
\text { F-44 years old }\end{array}$ & $\begin{array}{l}\text { Nodular } \\
\text { hyperplasia of } \\
\text { thyroid gland }\end{array}$ & $\begin{array}{l}+++ \\
\text { cytopl }\end{array}$ & $\begin{array}{l}++ \\
\text { cytopl }\end{array}$ & $\begin{array}{l}++ \\
\text { cytopl }\end{array}$ & $\begin{array}{l}+++ \\
\text { cytopl }\end{array}$ & negative & $\begin{array}{l}+ \\
\text { cytopl }\end{array}$ \\
\hline
\end{tabular}

SSTR 2B (SS-860, specific for 342-356 sequence), SSTR 3 (SS-850, specific for 381-395 sequence), SSTR 4 (SS-880, specific for 374-388 sequence) and SSTR 5 (SS-890, specific for 350-364 sequence). The immunohistochemical procedures were performed as previously described [18]. The working dilution of antibodies was 1: 1000 (diluted in 0.05 M TRIS buffer, pH 7.6 containing 2\% goat serum). Following overnight incubation in $4^{\circ} \mathrm{C}$ in humidified chamber with primary antibodies, the cells were treated with anti-rabbit IgG biotinylated goat antibody (1:800, DAKO, Denmark) and streptavidin complex (Strept ABC/ HRP, DAKO, Denmark). The immunoreaction was visualized with 3,3'-diaminobenzidine (DAB, DAKO, Denmark) solution. For negative controls the primary antibody was omitted and the normal goat serum was used.

The immunoreactive intensity for specific receptor proteins was scored semiquantitatively using a descriptive scale as follows: strong staining $(+++)$, moderate staining $(++)$, weak staining $(+)$ and pale staining (+/-). Subcellu- lar distribution pattern of SSTR subtypes - membranous or cytoplasmic was also determined.

\section{Real-Time PCR}

Total RNA was isolated from $1 \mathrm{~g}$ of frozen tissue using Magna Pure Compact RNA Isolation Kit Cat. No 04802 993001 (Roche Molecular Biochemicals) from nine patients. Total RNA was DNase treated using DNase I (RNase free) reagent (Ambion Cat. no AM2222). Firststrand cDNAs were synthesized from equal amounts of total RNA $(0,5 \mu \mathrm{g} /$ reaction) using oligo(dT) and iScript cDNA Synthesis Kit (Bio-Rad1Cat. No70-8890) according to the manufacturer's instruction. All primers were purchased in Oligo PAN Warszawa (Table 3) $[19,20]$. RT-PCR was performed using pairs of primers in reaction amplifying across a gradient of annealing temperatures to identify optimal reaction conditions for Real-Time PCR. Real Time PCR was performed using an iCycler iQ System (BioRad Cat No 170-8701, 170-9750). The rate of accumulation of amplified DNA was measured by continuous mon- 
itoring of SYBR Green I fluorescence. Melt Curve of the reaction products were in each experiment generated.

Specifically, quantitative real-time PCR on the iCycler iQ was performed in triplicate on $1 \mu \mathrm{l}$ of template cDNA per $25 \mu$ reaction. iQ supermix reactions consisted of iQ SYBR Green Supermix (Bio-Rad1Cat. No70-8882) at a final concentration $1 \times, 10 \mathrm{nM}$ fluorescein calibration dye, SYBR Green I, $500 \mathrm{nM}$ of each primer. Reactions were amplified in a 96-well thin-wall PCR plate (Bio-Rad Cat. No 223-9441) using the following PCR parameters: $95^{\circ} \mathrm{C}$ for $3 \mathrm{~min}$ followed by 50 cycles of $95^{\circ} \mathrm{C}$ for $10 \mathrm{sec}, 60^{\circ} \mathrm{C}$ for $30 \mathrm{sec}$, and $72^{\circ} \mathrm{C}$ for $30 \mathrm{sec}$. Melt-curve analysis was performed immediately following amplification by increasing the temperature in $0,4^{\circ} \mathrm{C}$ increments starting at $60^{\circ} \mathrm{C}$ for 85 cycles of $10 \mathrm{sec}$ each. The presence of a single PCR product was verified by the presence of a single melting temperature peak.

Real-time RT-PCR reactions for detection of the endogenous control gene (HPRT) were always run in parallel in each experimental run as a reference for accuracy of sample dilution.

For each experiment the 3-point standard curve was performed with commercial control RNA [Apllied Biosystems Control Total RNA Human 4307281 (100 $\mu$ l conc. $50 \mathrm{ng} / \mu \mathrm{l})$ - dilution $1 \times, 10 \times$ and $100 \times)]$.

\section{Results}

\section{Immunohistochemistry}

Immunoreactivity of investigated thyroid tissues was estimate in pathologically altered cells of thyroid cancers and benign lesions of the thyroid gland. The area of normal surrounding tissue was immunonegative in all investigated cases. Multiple SSTR subtypes were found to coexist in each case of investigated tissue (Table 2). Most of the specimens showed mixed distribution pattern of the receptors - cytoplasmic and membranous. Strong and moderate staining of SSTR 1 which was distributed both in the cytoplasm and the membranes or only in the cytoplasm was shown in 8 (88,8\%) specimens (Fig. 1),(Fig. 2). SSTR 2A was also characterized by mixed distribution - cytoplasmic and membranous. Strong and moderate staining was demonstrated in 4 cases $(44,4 \%)$ and in the remaining 4 cases $(44,4 \%)$ distribution of this SSTR subtype was fluctuated from weak to pale. In 4 specimens $(44,4 \%)$ strong to moderate staining of SSTR 2B was observed with both membranous distribution and in the area of the cell cytoplasm. In the other 4 cases the staining intensity was weak or pale. Staining for SSTR 3 was characterized by cytoplasmic distribution with various intensity. In $5(55,5 \%)$ out of 9 examined specimens SSTR 3 was found with strong or moderate intensity in the cell cytoplasm and the remaining 3 cases $(33,3 \%)$ showed weak to pale intensity of staining (Fig. 3). There was no immunostaining of the SSTR 1-3 subtypes in patient $\mathrm{nr} 6$ with lymphatic goiter. In this case the immunoreactivity of SSTR 1, 2A, 2B and 3 was negative in the thyroid follicular epithelium but pale to strong staining was observed in the lymphatic follicles. No presence of SSTR 4 was found in the $8(88,8 \%)$ of investigated cases with exception of $1(11,2 \%)$ specimen showing cytoplasmic distribution of this receptor subtype fluctuating from pale to strong (patient nr 2) (Fig. 4). Similarly to SSTR 3, SSTR 5 was also characterized by exclusively cytoplasmic distribution with strong and moderate intensity in 3 samples $(33,3 \%)$. Another $5(55,5 \%)$ cases demonstrated pale to moderate staining. In $1(11,2 \%)$ specimen the intensity of staining was from pale to strong (patient $\mathrm{nr} 2$ ).

Table 3: Primers sequences applied for quantitative Real-Time PCR

\begin{tabular}{|c|c|c|c|}
\hline Name & Sequence & Size of PCR product, bp & GenBank accession no. \\
\hline $\begin{array}{l}\text { SSTR 2A (forward) } \\
\text { SSTR 2A (reverse) }\end{array}$ & $\begin{array}{l}\text { 5'ATGCCAAGATGAAGACCATCAC 3' } \\
\text { 5'TGAACTGATTGATGCCATCCA 3' }\end{array}$ & $17 \mid[19]$ & NM 001050 \\
\hline $\begin{array}{l}\text { SSTR } 3 \text { (forward) } \\
\text { SSTR } 3 \text { (reverse) }\end{array}$ & $\begin{array}{l}\text { 5'CTGGGTAACTCGCTTGGTCATCTA 3' } \\
\text { 5'AGCGCCAGGTTGAGGATGTA 3' }\end{array}$ & $86[19]$ & NM 00105I \\
\hline $\begin{array}{l}\text { SSTR I (forward) } \\
\text { SSTR I (reverse) }\end{array}$ & $\begin{array}{l}\text { 5'TATCTGCCTGTGCTACGTGC 3' } \\
\text { 5'GATGACCGACAGCTGACTCA 3' }\end{array}$ & $217[20]$ & NM 001049 \\
\hline $\begin{array}{l}\text { SSTR } 4 \text { (forward) } \\
\text { SSTR } 4 \text { (reverse) }\end{array}$ & $\begin{array}{l}\text { 5'ATCTTCGCAGACACCAGACC 3' } \\
\text { 5'ATCAAGGCTGGTCACGACGA 3' }\end{array}$ & $321[19]$ & NM 001052 \\
\hline $\begin{array}{l}\text { SSTR } 5 \text { (forward) } \\
\text { SSTR } 5 \text { (reverse) }\end{array}$ & $\begin{array}{l}\text { 5'GTGACAACAGGACGCTGGT 3' } \\
\text { 5'TGGTGACGGTCTTCATCTTG 3' }\end{array}$ & I56 [20] & NM 001053 \\
\hline $\begin{array}{l}\text { HPRT (forward) } \\
\text { HPRT (reverse) }\end{array}$ & $\begin{array}{l}\text { 5'TGCTTTCCTTGGTCAGGCAGTAT 3' } \\
\text { 5'TCAAATCCAACAAAGTCTGGCTTATATC3' }\end{array}$ & $109[19]$ & NM 000194 \\
\hline
\end{tabular}




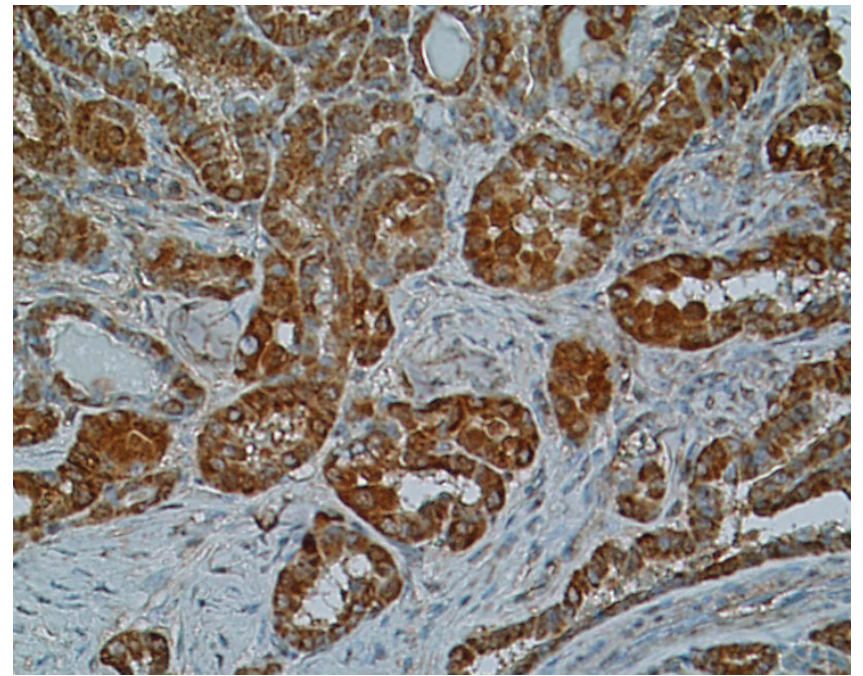

Figure I

Immunostaining of SSTR I in papillary carcinoma, patient $\mathrm{nr} 2(333508)(\times 200)$. Strong intensity of staining distributed in the cytoplasm.

\section{Real-Time PCR}

We consolidated result for endogenous control gene of hypoxanthine-guanine phosphoribosyltransferase (HPRT) as negative (score: 0,0 ) and according to this all remaining mRNAs were calculated relative to the amount of HPRT and given in arbitrary units. The diagram presented below show the mean results of 3 experiments for each primer (Fig. 5). SSTR 1 mRNA was expressed in all isolated tissues with different intensity. In 7 from 9 cases $(77,7 \%)$ it is correlated

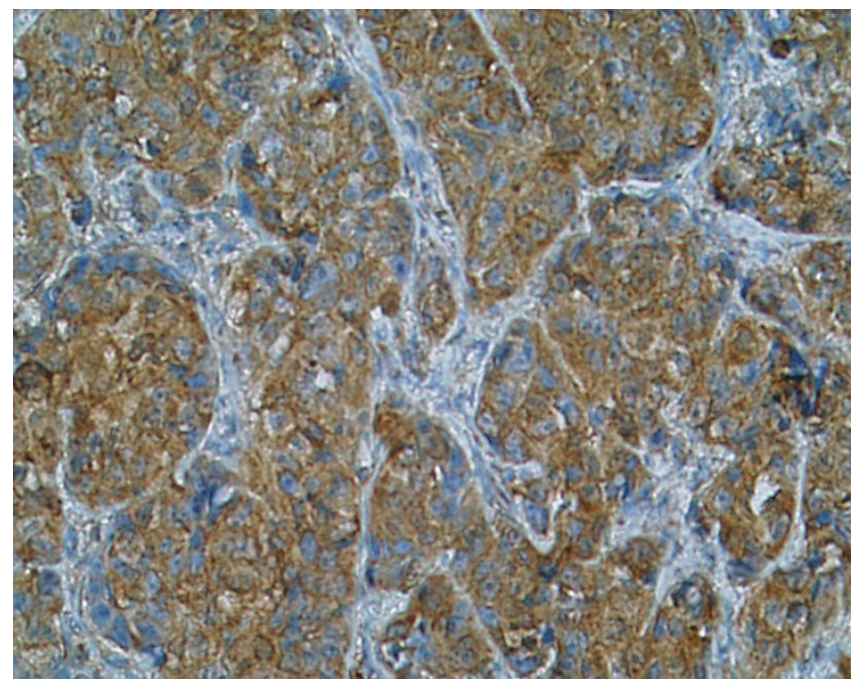

Figure 2

Immunostaining of SSTR I in poorly differentiated carcinoma, patient $\mathrm{nr} 3$ (334708) (× 200). Moderate staining with both cytoplasmic and membranous distribution.

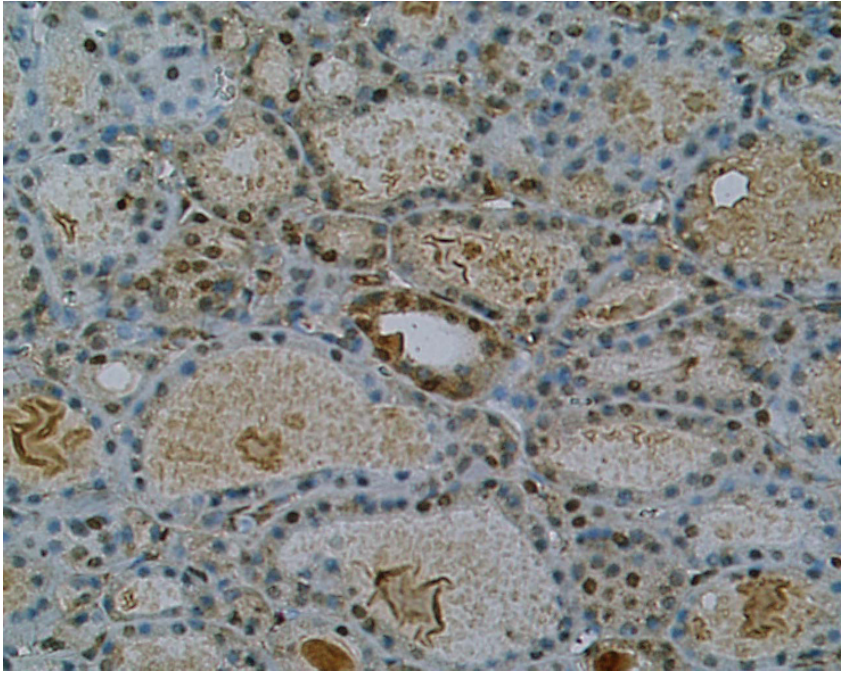

\section{Figure 3}

Weak immunostaining of SSTR 3 in non-malignant goiter, patient nr 9 (332 I 3 I) (× 200). Cytoplasmic distribution with weak intensity of staining.

with immunohistochemical investigation of SSTR 1 where intensity of staining was from moderate to strong. In 1 patient (nr 4) SSTR 1 mRNA was only slightly elevated while expression of SSTR 1 protein in IHC was strong. The inverse situation we observed in patient nr 6 where SSTR 1 mRNA was elevated while protein expression was negative. SSTR 2A mRNA was elevated in 6 patients $(66,6 \%)$ thus a good correlation of RT-PCR and IHC results was observed in patients: $1,2,7,8,9,10$. Patient nr 3 with poorly differen-

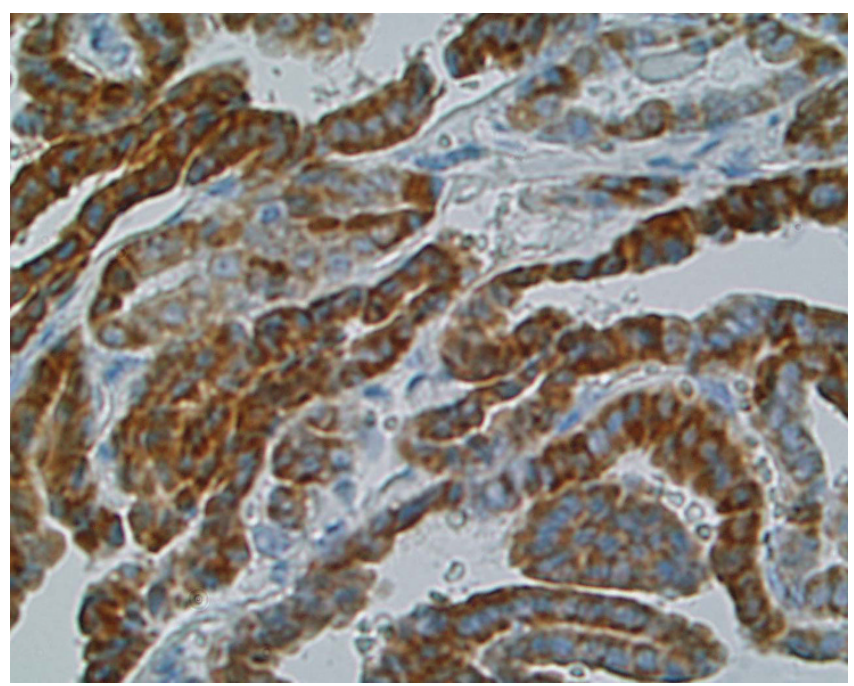

Figure 4

Immunostaining of SSTR 4 in papillary carcinoma, patient nr $2(333508)(\times 400)$. Cytoplasmic distribution of this receptor subtype fluctuates from pale to strong. 


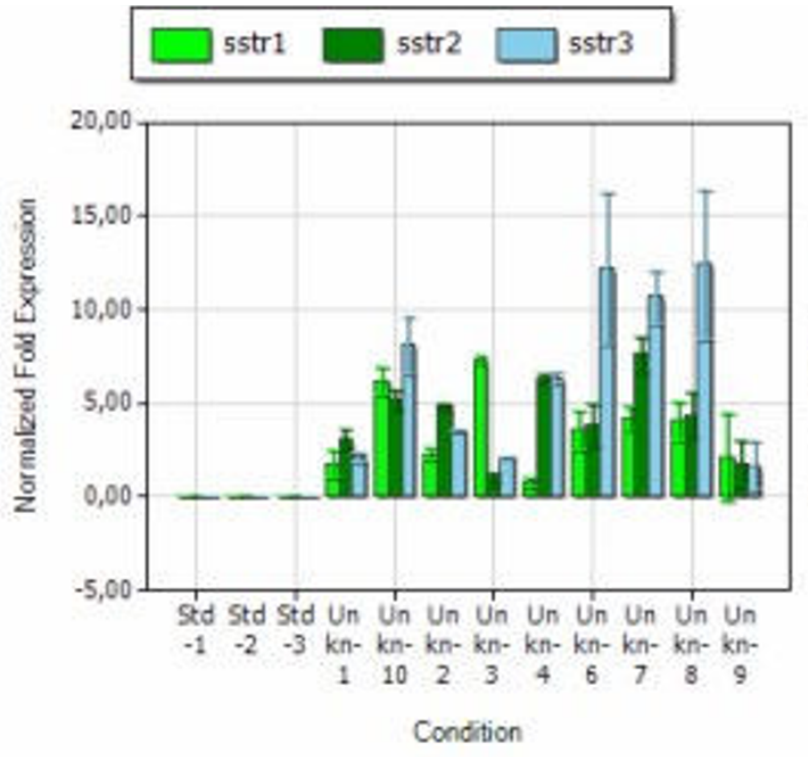

Gene Expression : sstr1-3.opd

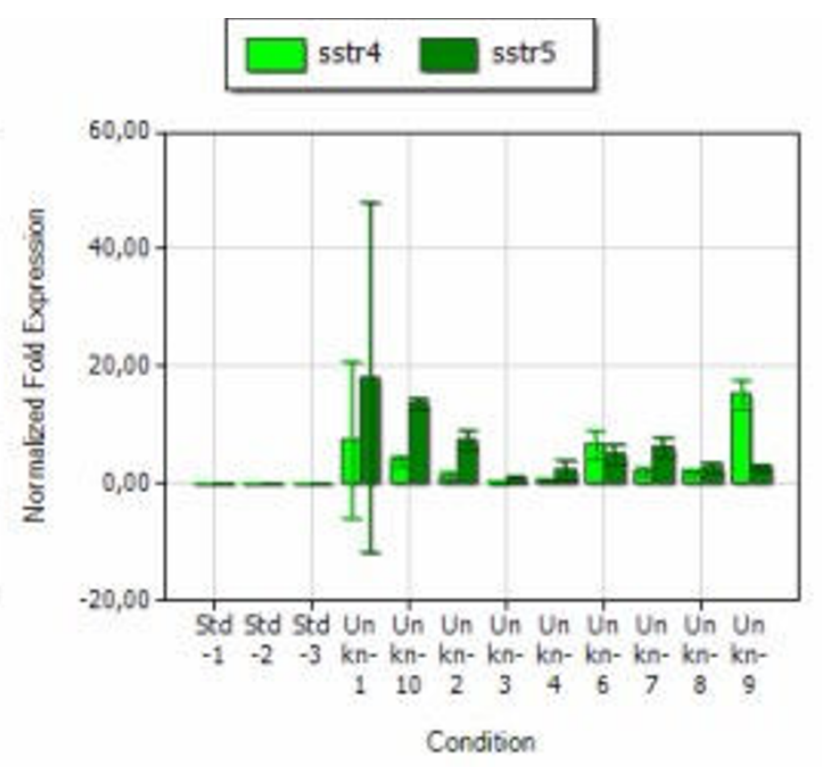

Gene Expression : sstr4-5.opd

\section{Figure 5}

Somatostatin I, 2A, 3, 4, 5 receptor subtypes gene expression determined by RT-PCR method. mRNAs for SST receptors subtypes were calculated relative to the amount of HPRT control gene and given in arbitrary units. Std-standard I,2,3 of endogenous control gene. Unkn - expression of SSTR mRNA in patients (I-4), (6-I0). sstr I, 2, 3, 4, 5 = SSTR I, 2A, 3, 4, 5 mRNA.

tiated carcinoma had expression of SSTR 2A protein with weak intensity (Fig. 6) and this result was also in agreement with low score of RT-PCR. It gives summary $77,7 \%$ of good correlation. The different situation appeared in patients $\mathrm{nr}$ 4 and $6(22,2 \%)$ were pale or negative immunostaining of SSTR 2A and 2B was not correlated with high score of SSTR 2A gene expression. The same results in these patients (nr $4,6)(22,2 \%)$ we observed in case of SSTR 3 subtype. Pale or negative immunohistochemical score was not correlated with high score of SSTR 3 gene expression. Immunostaining of SSTR 3 was in agreement with RT-PCR method in 7 cases (patients: $1,2,3,7,8,9,10)(77,7 \%)$ were strong and moderate staining corroborates with the presence of high and elevated score of SSTR 3 mRNA. Only two negative results of SSTR 4 mRNA estimation $(22,2 \%)$ were good correlated with negative immunohistochemical staining (patients: 3,4). No immunostaining of SSTR 4 was observed in patients: $1,6,7,8,9,10$ but a slightly or elevated gene expression was observed in them. In 1 sample (patient nr 2) exceptional fluctuated distribution of SSTR 4 from pale to strong was correlated with faintly detectable gene expression. In all 9 samples (100\%) high or low score of SSTR 5 mRNA expression was well correlated with strong to pale IHC staining.

\section{Discussion}

We demonstrated in our investigation that somatostatin subtype receptors are widely distributed in human thyroid diseases with different intensity and cellular localization. It is consists with earlier reports of England et al.[12] who find positive immunostaining in number of investigated tissues in relation to type of thyroid pathology. The cited authors have found that for 6 investigated cases with papillary carcinomas 5 patients had SSTR 1, 2B, 3 and 4 receptor subtype $(83 \%)$. In all of them SSTR 5 was observed $(100 \%)$ and SSTR $2 A$ was expressed in 4 cases $(66 \%)$. In multinodular goiters SSTR 2A, 3 and 4 were expressed in $82 \%$ cases, SSTR 2B, 5 in 94\% and SSTR 1 was expressed in $88 \%$. In our IHC study in $88,8 \%$ of investigated cases we find SSTR 1 with strong and moderate immunostaining. In contrast, the expression of SSTR $2 \mathrm{~A}$ and $2 \mathrm{~B}$ was found in 44,4\%, SSTR 3 in 55,5\%, SSTR 4 in 11,2\% and SSTR 5 in 33,3\% of cases. Our results are conflicting with England et al. in the scope of SSTR 4, where we did not detect SSTR 4 at the protein level in multinodular goiter (MNG) cases using the immunohistochemical method. Maybe other type of specific anti-SSTR 4 antibody was used in both experiences. Thus our results show that SSTR 1 but not other subtypes is the dominant form in the thyroid gland tumors and hyperplasias. The molecular biology method results prove the predominance of SSTR 1, 2A and 3 mRNAs. These data suggest that despite of the conventional somatostatin analogs: octreotide and lanreotide, multiligand analogs such as SOM 230 or KE 108 or selective ligands of SSTR 1 may be useful in thyroid tumors treatment. Our material is to scarce to estimate the 


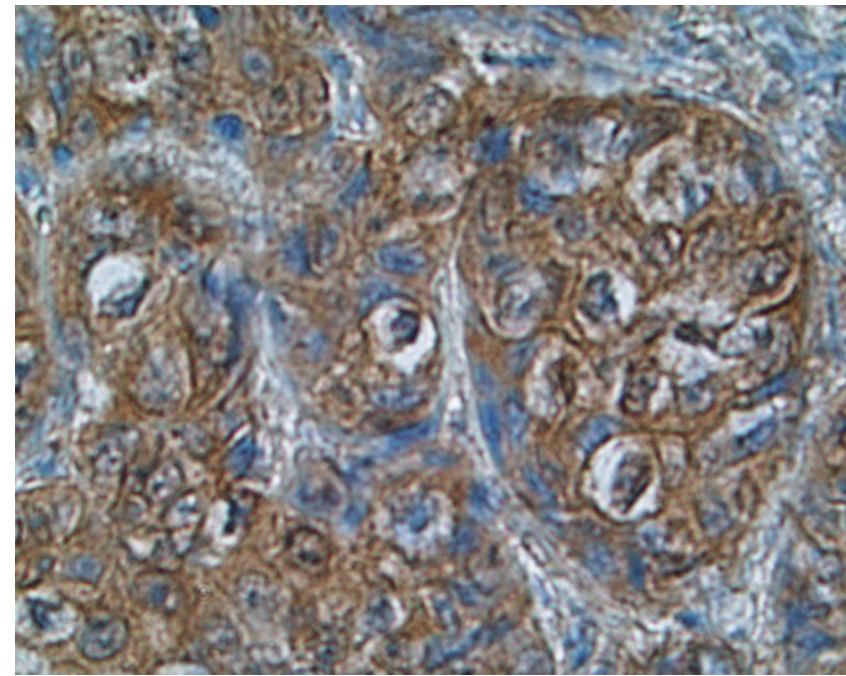

Figure 6

Immunohistochemical staining of SSTR 2A in poorly differentiated carcinoma, patient nr 3 (334708) ( $x$

400). Weak intensity of SSTR $2 A$ protein staining with mixed cytoplasmic and membranous distribution.

possible differences between benign and malignant thyroid lesions, however, poorly differentiated cancers characterize by low expression of SSTR 2 (Fig. 6). It is worth interesting that in cancer tissue the expression of SSTR 1 , SSTR 2A, SSTR 2B may be membrane or cytoplasmic (Fig. 1), (Fig. 2), (Fig 6), whereas in non-cancer tissue the expression of these receptors was only cytoplasmatic (Fig. 7 ). This observation may suggest the higher responsiveness of SSTR in highly differentiated malignant tumors than in benign lesions. In the Druckenthaner's experiences [13] SSTR 2 immunohistochemistry was positive in $87 \%$ of the samples with thyroid tumors. SSTR 2 mRNA expression well correlated with immunohistochemical staining pattern in $13 / 16$ samples $(81 \%)$. In this study the SSTR 2 mRNA was the predominantly expressed on thyroid tumors $(68 \%)$, SSTR 5 and SSTR 3 mRNAs were less predominant ( $50 \%$ and $31 \%$ respectively). No SSTR 3 and SSTR 4 mRNAs was found in any specimens. Also ForssellAronsson's group [21] reported that in surgical specimens SSTR 1, 3, 4, 5 mRNAs were frequent expressed but SSTR 2 mRNA was not detected. Similar results were observed earlier by Ain [10] but in the thyroid carcinoma cell lines not in surgically isolated tissues. Most thyroid cancer cell line monolayers and xenografts expressed SSTR 3 and SSTR 5 mRNAs whereas SSTR 2 mRNA was only faintly detectable. In our experiences we found positive confirmation of both methods in $77,7 \%$ for SSTR 1, 2A, 3 subtypes, in $22,2 \%$ for SSTR 4 and in $100 \%$ for SSTR 5 . The lack of good correlation between receptor protein expression (positive immunostaining) and receptor gene expres- sion (negative by RT-PCR and vice versa) in our study needs explanations by future examinations. Several causes should be taken into consideration, e.g. the expression of SSTR mRNA in tissue elements other than thyroid epithelial cells, like vascular endothelia, parafollicular cells and lymphoid cells which can lead to the false positive results of RT-PCR examination or the lower sensitivity of IHC which in turn can produce the false negative results. Lastly, the expression on the mRNA and protein levels should not to be always synchronized.

\section{Conclusion}

We proved that somatostatin receptor subtypes are frequently expressed in pathologically altered thyrocytes, in contrast to normal thyroid follicular epithelium. SSTR 1 protein was expressed in $77,7 \%$ of investigated cases, SSTR 2A and 2B both in 44,4\%, SSTR 3 in 55,5\%, SSTR 4 in $11,2 \%$ and SSTR 5 in $33,3 \%$. SSTR 1 is the dominant form in the thyroid gland tumor and hyperplasia. A good correlation with SSTR 1 receptor gene expression was observed in $77,7 \%$ of investigated cases. Immunohistochemical estimation of SSTR $2 \mathrm{~A}$ and 3 was agree with RTPCR method in $77,7 \%$, only $22,2 \%$ of results of SSTR 4 mRNA estimation were correlated with immunohistochemical staining and SSTR 5 mRNA was good correlated with IHC staining in $100 \%$ tissues. It suggests that somatostatin multiligand analogs or selective SSTR 1 agonists may represent a further useful approach for the thyroid tumors treatment. The expression of somatostatin receptor subtypes in thyroid tumors needs father studies concerning greater and more differentiated group of patients.

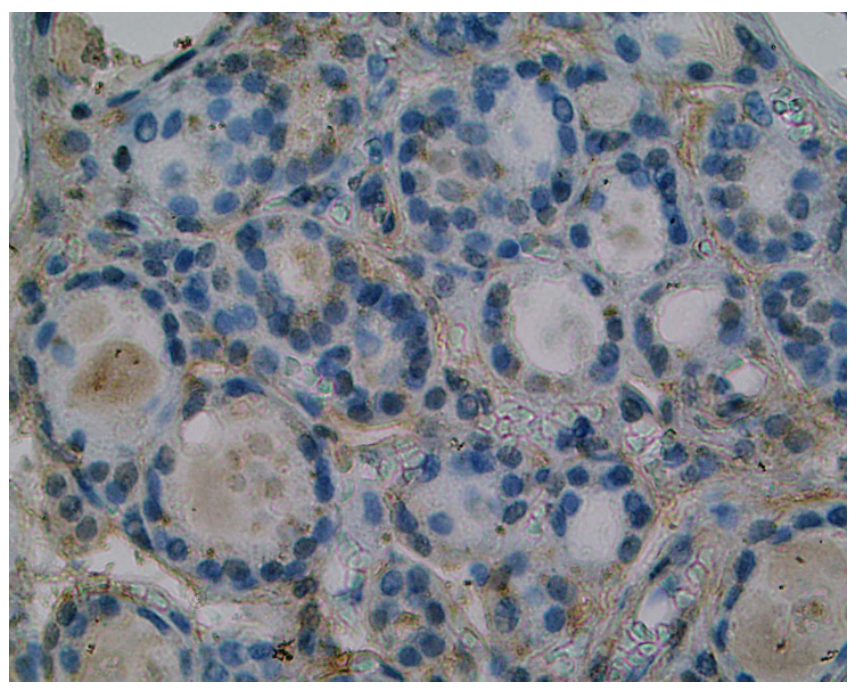

Figure 7

Pale immunostaining of SSTR 2A in non-malignant goiter, patient nr 9 (332131) (× 400). Pale cytoplasmic expression of this receptor subtype. 


\section{Abbreviations}

mem: membranous localization; cytopl: cytoplasmatic localization; strong staining $(+++)$, moderate staining $(++)$, weak staining $(+)$ and pale staining $(+/-)$; SST: somatostatin; SSTR: somatostatin receptor subtype; RT-PCR: real time polimerase chain reaction; RT-PCR: reverse transcriptase polimerase chain reaction; ISH: in situ hybridisation; IHC: immunohistochemistry; NET: neuroendocrine tumors in gastrointestinal tract; MTC: medullary thyroid carcinoma; MNG: multinodular goiter; mRNA: messenger ribonucleic acid; HPRT: hypoxanthineguanine phosphoribosyltransferase control gene.

\section{Competing interests}

The authors declare that they have no competing interests.

\section{Authors' contributions}

HP carried out the immunohistochemistry studies and drafted the manuscript. TS obtained thyroid tissues during surgery. RK established histopathological diagnosis. EB carried out the molecular biology studies. MP supervised the experiences, helped to draft and revised the manuscript and provided general support. All authors read and approved the final manuscript.

\section{Acknowledgements}

The author would like to thank Mrs Maria Jaranowska, Mrs Małgorzata Jędrzejewska and Mrs Anna Oplatowska for their skillful technical assistance.

\section{References}

I. Patel YC, Greenwood M, Kent G, Panetta R, Srikant CB: Multiple genes transcripts of the somatostatin receptor SSTR 2: tissue selective distribution and CAMP regulation. Biochem Biophys Res Commun 1993, 192:288-294.

2. Hoyer D, Bell GI, Berelowitz M, Epelbaum J, Feniuk W, Humphrey PP, O'Carroll AM, Patel YC, Schonbrunn A, Taylor JE, Reisine T: Classification and nomenclature of somatostatin receptors. Trends Pharmacol Sci 1995, I 6:86-88.

3. Reisine T, Bell G: Molecular Biology of Somatostatin Receptors. Endocrine Reviews 1995, I6(4):427-442.

4. Patel YC: Molecular pharmacology of somatostatin receptors subtypes. Journal of Endocrinological Investigation 1997, 20:348-367.

5. de Herder WW, Hofland LJ, Lely AJ Van der, Lamberts SW: Somastostatin Receptors in gastroenteropancreatic neuroendocrine tumours. Endocrine-Related Cancer 2003, 1 0:45 I-458.

6. Pawlikowski $M$ : The incidence of somatostatin receptors in human neoplasms in the light of ex vivo-in vitro studies. Polish Journal of Endocrinology 2006, 57(3):238-243.

7. Reubi JC, Chayvialle JA, Franc B, Cohen R, Calmettes C, Modigliani E: Somatostatin receptors and somatostatin content in madullary thyroid carcinomas. Lab Invest 199I, 64(4):567-573.

8. Mato E, Matias-Guiu X, Chico A, Webb SM, Cabezas R, Berna L, de Leiva A: Somatostatin and Somatostatin Receptor Subtype Gene Expression in Medullary Thyroid Carcinoma. I Clin Endocrinol Metab 1998, 83(7):24I7-2420.

9. Zatelli MC, Piccin D, Tagliati F, Luchin A, Vignali C, Margutti A, Bondanelli M, Pansini GC, Pelizzo MR, Culler MD, degli Uberti EC: Selective Activation of Somatostatin Receptor Subtypes Differentially Modulates Secretion and Viability in Human Medullary Thyroid Carcinoma Primary Cultures: Potential Clinical Perspectives. J Clin Endocrinol Metab 2006, 9 I(6):2218-2224.

10. Ain KB, Taylor KD, Tofiq S, Ventkataraman G: Somatostatin Receptor Subtype Expression in Human Thyroid and Thy- roid Carcinoma Cell Lines. I Clin Endocrinol Metab 1997, 82(6): | $857-1862$

II. Tisell LE, Ahlman H, Wangberg B, Kolby L, Fjalling M, Forssell-Aronsson E, Molne J, Nilsson O: Expression of somatostatin receptors in oncocytic (Hurthle cell) neoplasia of the thyroid. British Journal of Cancer 1999, 79:1579-1582.

12. England RJA, Bedford KJ, Karsai L, Atkin SL: Somatostatin receptor expression in thyroid disease. Endocrine Abstracts 2003, 5:P269.

13. Druckenthaner M, Schwarzer C, Ensinger C, Gabriel M, Prommegger R, Riccabona G, Decristoforo C: Evidence for Somatostatin receptor 2 in thyroid tissue. Regulatory peptides 2007, I 38(I):32-39.

14. Pawlikowski M: Somatostatin Receptors in Human Tumors In Vitro Studies. In Somatostatin Analogs in Diagnostics and Therapy Edited by: Marek Pawlikowski. Landes Bioscience; 2007:39-46.

I5. Pisarek H, Pawlikowski M: Immunohistochemical localization of somatostatin receptors subtypes $\mathbf{I - 5}$ in non pituitary endocrine tumours. XVIII Congress of the Polish Society of Endocrinology, Poland - Polish Journal of Endocrinology 2005, 4(56):SI I-5.

16. Pisarek H, Stępieñ T, Kubiak R, Pawlikowski M: Somatostatin receptors in human adrenal gland tumors - immunohistochemical study. Folia Histochemica et Cytobiologica 2008, 46(3):25 I-257.

17. Pawlikowski M, Pisarek H, Kunert-Radek J, Radek A: Immunohistochemical Detection of Somatostatin Receptor Subtypes in „Clinically Nonfunctioning" Pituitary Adenomas. Endocrine Pathology 2003, I 4(3):231-238.

18. Schulz S, Schulz St, Schmitt J, Wiborny D, Schmidt H, Olbricht S, Weise W, Roessner A, Gramsch C, Hollt V: Immunocytochemical Detection of Somatostatin Receptors sst I, sst2A and sst3 in Paraffin - embedded Breast Cancer Tissue Using Subtype specific Antibodies. Clinical Cancer Research 1998, 4:2047-2052.

19. Ferone D, Pivonello R, van Hagen M, Dalm V, Lichtenauer-Kaligis E Waaijers M, van Koetsveld PM, Mooy DM, Colao A, Minuto F, Lamberts SWJ, Hofland LJ: Quantitative and functional expression of somatostatin receptor subtypes in human thymocytes. Am J Physiol Endocrinol Metab 2002, 283:El056-El 066.

20. de Sa SV, Correa-Giannella LM, Machado MC, de Souza JJS, Pereira MAA, Patzina RA, Sigueira SAC, Machado MCC, Giannella-Neto D: Somatostatin receptor subtype 5 (SSTR5) mRNA expression is related to histopathological features of cell proliferation in insulinomas. Endocrine-Related Cancer 2006, I 3:69-78.

21. Forssell-Aronsson EB, Nilsson O, Benjegard SA, Kolby L, Bernhardt P, Molne J, Hossein Hashemi S, Wangberg B, Tisell LE, Ahlman $\mathrm{H}$ : I I I In-DTPA-D-Phe I-Octreotide Binding and Somatostatin Receptor Subtypes in Thyroid Tumors. The Journal of Nuclear Medicine 2000, 4 I (4):636-642.

\section{Publish with Bio Med Central and every scientist can read your work free of charge}

"BioMed Central will be the most significant development for disseminating the results of biomedical research in our lifetime. "

Sir Paul Nurse, Cancer Research UK

Your research papers will be:

- available free of charge to the entire biomedical community

- peer reviewed and published immediately upon acceptance

- cited in PubMed and archived on PubMed Central

- yours - you keep the copyright
BioMedcentral 